\title{
Intratumoral molecular genetic heterogeneity of glioblastomas
}

\author{
P.V. Nikitin, M.V. Ryzhova, A.A. Potapov, S.A. Galstyan, D.S. Kim, \\ T.N. Panina, S.V. Shugai, D.V. Starovoitov, E.A. Khokhlova, I.V.Zubova \\ N.N. Burdenko National Medical Research Center of Neurosurgery of the Ministry of Health of Russia, Moscow, Russia
}

\begin{abstract}
Intratumoral molecular genetic heterogeneity is not a less significant challenge in modern oncology than the intertumoral. The presence of cell populations within the same tumor, differing in their molecular properties, translated into phenotypic features of the cells, is one of the reasons for the inefficiency of many developments in the field of tumor therapy and the basis for the progression of malignant neoplasms. The issue under consideration is very relevant for glioblastoma (GBM) - being one of the deadliest human tumors; it practically does not lend itself to even promising experimental treatment methods. Therefore, this paper reviews intratumoral heterogeneity. The review in this aspect examines new experimental data, including those obtained using single-cell technologies, in particular, the key cell populations that make up the pool of tumor cells in glioblastoma, and their molecular metamodules, the presumptive role of some cell populations and their subpopulations in providing tumor malignancy properties. A promising groundwork for fundamentally new approaches to creating personalized diagnostic and therapeutic methods is indicated.
\end{abstract}

Keywords: glioblastoma, intratumoral heterogeneity, glioblastoma genetics, single-cell sequencing

Corresponding author: Pavel V. Nikitin. E-mail: nikitinpaulv@yandex.ru

For citation: Nikitin P.V., Ryzhova M.V., Potapov A.A., Galstyan S.A., Kim D.S., Panina T.N., Shugai S.V., Starovoitov D.V., Khokhlova E.A., Zubova I.V. Intratumoral molecular genetic heterogeneity of glioblastomas. Clin. exp. morphology. 2020;9(4):5-11. DOI:10.31088/CEM2020.9.4.5-11.

Funding. The study was carried out within the framework of state budget funding.

Conflict of interest. The authors declare no conflict of interest.

Received 25.03.2020. Received in revised form 12.08.2020. Accepted 26.10.2020.

\section{Внутриопухолевая молекулярно-генетическая гетерогенность глиобластом \\ П.В. Никитин, М.В. Рыжсова, А.А. Потапов, С.А. Галстян, Д.С. Ким, Т.Н. Панина, С.В. Шугай, Д.В. Старовойтов, Е.А. Хохлова, И.В. Зубова}

ФГАУ Национальный медицинский исследовательский центр нейрохирургии имени академика Н.Н. Бурденко Минздрава России, Москва, Россия

Внутриопухолевая молекулярно-генетическая гетерогенность - не менее важный вызов для современной онкологии, чем межопухолевая. Наличие клеточных популяций внутри одной опухоли, различающихся по своим молекулярным свойствам, транслируемым в фенотипические особенности клеток, является одной из причин неэффективности многих разработок в области терапии опухолей и основой для прогрессирования злокачественных новообразований. Рассматриваемый вопрос весьма актуален для глиобластомы (ГБ), так как, будучи одной из самых смертельных опухолей человека, она практически не поддается даже многообещающим экспериментальным методам лечения. В связи с этим настоящий обзор посвящен внутриопухолевой гетерогенности. В обзоре в указанном аспекте рассматриваются новые экспериментальные данные, в том числе полученные с помощью single-cell технологий, в частности ключевые клеточные популяции, составляющие пул опухолевых клеток в глиобластоме, и их молекулярные метамодули, предположительная роль некоторых клеточных популяций и их субпопуляций в обеспечении свойств злокачественности опухоли. Обозначается перспективный задел для принципиально новых подходов в создании персонализированных диагностических и лечебных методов.

Ключевые слова: глиобластома, внутриопухолевая гетерогенность, генетика глиобластом, single-cell секвенирование 
Для корреспонденции: Павел Владимирович Никитин. E-mail: nikitinpaulv@yandex.ru

Для цитирования: Никитин П.В., Рыжова М.В., Потапов А.А., Галстян С.А., Ким Д.С., Панина Т.Н., Шугай С.В., Старовойтов Д.В., Хохлова Е.А., Зубова И.В. Внутриопухолевая молекулярногенетическая гетерогенность глиобластом. Клин. эксп. морфология. 2020;9(4):5-11. DOI:10.31088/ CEM2020.9.4.5-11

Финансирование. Исследование выполнено в рамках государственного бюджетного финансирования. Конфликт интересов. Авторы заявляют об отсутствии конфликта интересов.

Статья поступила 25.03.2020. Получена после рецензирования 12.08.2020. Принята в печать 26.10 .2020

\section{Introduction}

Intratumoral molecular genetic heterogeneity issues are extremely important for a modern comprehensive understanding of the carcinogenesis processes. The variability of genetic, proteomic, and epigenetic parameters not only within the same histological variant of the tumor but within the same tumor with heterogeneous cell populations is attracting more and more attention of researchers $[1,2]$. Different cell populations with heterogeneous molecular properties can also have a variable malignant potential, which is essential from a prognostic point of view. Precise assessment of the most active tumor cell population's molecular properties will significantly increase patients' prognosis determination accuracy. In addition, intratumoral heterogeneity can be one of the key reasons for both drug and radiation treatment ineffectiveness [3]. Thus, the determination of the molecular properties of different cell populations within one tumor can allow more efficiently solving clinical and therapeutic problems at once, including the formation of new, genuinely innovative diagnostic, prognostic and therapeutic concepts within the paradigm of personalized medicine.

This approach is also one of the pressing issues for glioblastoma (GBM) research. GBM occupies a leading position among primary malignant tumors of the central nervous system (CNS): it accounts for $15.1 \%$ of all primary brain tumors and $46.1 \%$ of primary malignant brain tumors [4]. The five-year survival rate for this disease amounts to $5.1 \%$ [4]. The high mortality and low efficiency of modern therapeutic approaches, both conventional and experimental, depend largely on the variability and heterogeneity of GBM. We have earlier reviewed the variability and diversity of the GBM molecular profile in the intertumoral aspect [5]. In this paper, we will delve into GBM intratumoral heterogeneity issues due to their importance for the modern understanding of gliomagenesis mechanisms.

Most GBMs demonstrate a significant degree of heterogeneity already at the light-optical level: cells and groups of cells are detected in the tumor, which differ significantly from each other in their morphological properties. Two main types of intratumoral heterogeneity of GBM can be distinguished - histological and molecular heterogeneity.

\section{Histological intratumoral heterogeneity}

Histological heterogeneity of GBM is characterized, first of all, by the presence of many different morphological types of cells. Some of them can even simulate or imitate other tumors, which often explains their naming. Other GBM type names are determined by the tumor cells' key histogenetic and morphological characteristics [6].

Thus, in some cases, we diagnose a small-cell variant, consisting of small monomorphic cells with rounded or slightly elongated hyperchromic nuclei with a minimum amount of cytoplasm, a small nuclear atypia, and high mitotic activity. Simultaneously, this tumor subtype demonstrates a relatively high frequency of EGFR mutations and amplifications, reaching $70 \%$, and a relatively low TP53 gene alteration frequency [7]. In addition, there is the so-called primitive neuronal cytological variant. With this variant, an increased density of the cell layer and a high nuclear-cytoplasmic ratio are observed. Also, positive neuronal marker expression is often revealed. Besides, this subtype is defined by a high frequency (30-40\%) of tumor dissemination through the cerebrospinal fluid and a high frequency ( $40 \%)$ of $M Y C N$ or $M Y C$ amplification, which brings this variant closer to embryonic tumors $[8,9]$. The oligodendroglial component is represented by medium-sized cells with a centrally located rounded nucleus surrounded by an optically empty cytoplasm in the form of a light rim. Such tumors may have a better prognosis than GBM with conventional histopathology [9]. In some GBMs, hemistocytic, multinucleated giant cell, granular, lipid-reach, and metaplastic components and cytological variants are also found $[6,10,11]$. At the same time, individual cellular components are found in many GBMs, mainly as a minor component.

\section{Molecular intratumoral heterogeneity}

The next step in the GBM molecular characterization was a differentiated assessment of various cell groups' molecular properties within a single tumor. One of the first works on this topic, pronounced heterogeneity was found within one tumor at the transcriptional level [1]. According to A. P. Patel et al. [1], the mosaic nature of the amplification processes of tyrosine kinase receptors (TKR) and excessive activation of signaling pathways contribute 
to GBM target therapy resistance. Mosaic expression of $E G F R, P D G F R A, P D G F A$, fibroblast growth factor receptor type 1 (FGFR1), fibroblast growth factor type $1(F G F 1)$, notch receptor type 2 (NOTCH2), JAG1 protein, and other receptors and ligands of signaling pathways involved in the GBM development was found. These data suggest that heterogeneous expression and mutational status of TKR and other signaling molecules in individual GBM tumor cells may interfere with therapy targeting receptors of signaling proliferative cascades or signaling through tyrosine kinase receptors [1].

A population of GBM cells with stem properties, the so-called glioma stem cells (GSCs), was identified in the spirit of the principles of GBM intratumoral functional heterogeneity development [12]. GSCs are similar to neuronal stem cells in their genetic, epigenetic, and proteomic features [13]. Many authors believe that GSCs are the main culprits in tumor insensitivity to chemotherapy and radiation and serve as one of the main reasons for malignant glioma recurrence after surgical treatment $[14,15]$.

Two different subtypes of GSCs have been identified by whole-genome profiling (ss proneural and mesenchymal) [16]. Mesenchymal GSCs, apparently, mainly arise in primary GBM, which are formed de novo, while proneuralGSCs can be found in some WHO Grade III gliomas and GBM, although in this case pronounced phenotypic shifts between different subtypes of GSCs during the GBM progression are possible [16-18]. Proneural GSCs can acquire therapeutic resistance and more aggressive characteristics by shifting their molecular and phenotypic subtypes towards mesenchymal GSCs [17]. Mesenchymal GSCs are markedly more resistant to radiation therapy than their proneural counterparts, and the effect of radiation on proneuralGSCs activates the expression of molecular markers associated with mesenchymal differentiation $[16,17,19]$. Accordingly, markers associated with the mesenchymal phenotype (e.g., YKL40, CD109, and CD44) correlate with increased radioresistance and lower overall patient survival [20].

A. Sottoriva et al. [20] developed a unique scheme for neurosurgical sampling of GBM tissue from different spatially separated points in the same tumor in 11 patients. Each tumor sample underwent a comprehensive genomic analysis. The authors identified many cytogenetic rearrangements typical for GBM, particularly EGFR amplification and addition, and $M E T, C D K 6, M D M 4, A K T 3$, PDGFRA amplification. At the same time, it was shown that some of these driver chromosomal aberrations differed by pronounced heterogeneity within the same tumor, including an increase in the number of copies/amplification of the PDGFRA, MDM4, and AKT3 genes in some cells, as well as the heterogeneous distribution of deletion of the genomic locus containing the PTEN anti-oncogene in cells. Moreover, heterogeneity was not limited to genome regions containing genes previously associated with the GBM development. Fragments of tumor tissue from the same patient had a common genomic profile, indicating a clonal origin, but they demonstrated a remarkable variety of cytogenetic rearrangements present in different fragments of the same tumor. For a more detailed study of the tumor's evolution in each patient, the phylogenetic series of tumor cells were reconstructed based on the chromosomal aberration number. It was found that during the first appearance of a malignant clone, the $C D K N 2 A / B$ gene is deleted, and the $E G F R, C D K 6$, and $M E T$ genes are amplified. Later molecular events in GBM cells most often occur in genomic regions containing the PDGFRA, PTEN, and TP53 genes. Subsequently, the original tumor clone can divide into several subclones. In particular, the division of one of the GBMs into a subclone with $P D G F R A$ amplification and another subclone with $P T E N$ and $R B 1$ deletions was shown. The latter formed three more subclones, one of which demonstrated AKT3 and MDM4 gene amplification [20].

In another work, M. Aubry et al. [21] studied changes in the copy number of chromosome fragments in different tumor zones to determine the temporal spectrum of intratumoralclonal evolution. The authors confirmed that changes in the copy number of 7 and 10 chromosomes and, namely, $C D K N 2 A / B$ deletion and $E G F R$ amplification are among the earliest events in the GBM development. Other changes, such as PDGFRA, MDM2, and MDM4 amplification, have also been identified as important events occurring at different tumor growth stages, depending on the case. The authors found a significant difference in gene expression level between the brain's area infiltrated by the tumor and the macroscopically normal brain. The most significant differences were observed in the VEGF, CD44, GFAP, EZH2, CHI3L1, NES, and IGFBP2 expression [21].

Later, K.Abou-El-Ardat et al. conducted a comprehensive research of 12 growth foci of multifocal GBM from six patients. The authors showed that multifocal GBM genetically resemble primary GBM. Comparison of tumor growth foci of different localization in the same patient confirmed their monoclonal origin. The researchers found that $E G F R$ and $C D K N 2 A / B$ gene aberrations occurred in all patients. This unexpectedly high incidence reflects the clear genetic signature of multifocal GBM and may explain their high grade and invasive growth. Surprisingly, the types of mutations in different genes differed in different tumor focus locations in a particular patient. For example, different PTEN, TP53, EGFR, and CDKN2A/B mutations and aberrations were found in different tumor nodes, which, therefore, must have occurred independently in the late period of carcinogenesis. Also, chromothripsis (massive 
simultaneous multiple rearrangements of cell chromosomes) was identified as a late molecular event in tumor progression in multifocal GBM. In some cases, the TP53 mutation was an early event. Only the loss of one copy of PTEN and point mutations of the TERT gene promoter were early molecular events in all patients [22].

\section{Clustering GBM cells using single-cell technologies}

The most important work in understanding intratumoral heterogeneity and assessing the clonal evolution of different populations of tumor cells in GBM was the work of C. Neftel et al. The authors performed single-cell RNA sequencing using biopsy samples of tumors from 28 patients, including both adult and pediatric populations, in a comprehensive study of both intertumoral and intratumoral heterogeneity in GBM, IDH-wild type. A total of 7930 GBM cells were submitted for the analysis [23].

C. Neftel et al. identified expression programs that differ between cells in each tumor and then searched for recurrent programs ("metamodules") that were detected in different tumors to comprehensively characterize the intratumoral heterogeneity of malignant cells [23]. In this study, a hierarchical clustering of cells was carried out separately for each tumor based on the expression levels of all cellular genes. $44 \%$ of transcriptome signatures were associated almost exclusively with genes of the cell cycle. All remaining expression profiles were subjected to further analysis in order to clarify their biological significance. Expression signatures were significantly similar between different tumors, indicating that, despite the global differences between tumors, these intratumoral heterogeneity models reflect the fundamental processes common to most GBMs. Further clustering of expression profiles made it possible to distinguish four main groups of cells in GBM, two of which were additionally subdivided into two subgroups. Thus, six so-called metamodules of tumor cells were found, each consisting of 39-50 genes, and each metamodule was obtained from at least six tumors. In particular, two metamodules with high expression of mesenchymal differentiation genes (for example, vimentin) have been identified. One of these metamodules is closely related to hypoxia genes, stress response, and glycolytic metabolism genes (for example, ENO2 and LDHA). The authors defined them as mesenchymal-like (MES) metamodules: hypoxia-independent (MES1) and -dependent (MES2) signatures.

The other four metamodules have been associated with genes of neuronal development and neurogenesis characteristic for neuronal/glial lineages or progenitor cells. They included astrocytic markers in one of the metamodules (S100B, GFAP, SLC1A3, GLAST, and MLC1), oligodendroglial line markers in another metamodule (OLIG1,
$O M G$, PLP1, PLLP, TNR, and ALCAM), signatures of stem cells and neuronal progenitors in two other metamodules, including markers of neuronal progenitor cells ( $S O X 4$, $S O X 11$, and $D C X$ ). It was found by consistently comparing the obtained metamodules with the signatures of neuronal cells from the fetal and adult brain tissue and astrocytic, as well as oligodendroglial tumors, Grade II, that metamodules mimic different types of cellular developmental programs but with significant distortions compared to normal variants. These modules are called astrocyte-like (AC-like), oligodendrocyte-progenitor-like (OPC-like), and neural progenitor-like (NPC-like). NPC-like were further subdivided into two subtypes (NPC1 and NPC2), which differed in the inclusion of OPC-like-related genes in NPC1 (for example, $O L I G 1$ and $T N R$ ) compared to NPC2, where neuronal lineage genes exclusively prevailed in transcriptional profiles (for example, STMN1). In general, the picture of intratumoral heterogeneity of GBM is primarily described by four cellular conditions and transcriptome signatures, including NPC-like, OPC-like, AC-like, and MES. These conditions were found in most tumors in both adults and children [23].

The authors also classified all tumors' cells by the expression level of metamodules and cell cycle programs. Between $3 \%$ and $51 \%$ of cells in each tumor were identified as expressing cell cycle genes and entering mitosis. Proliferating cells were especially abundant in OPC-like and NPC-like modules, and they were most actively expressed in tumors in children. These observations are consistent with previous studies of IDH mutant diffuse gliomas, whose cellular drivers are proliferating NPC-like and OPC-like [23]. However, in GBM, unlike other classes of gliomas, other types of cells with different expression modules - AC-like and MES cells - also contain significant subsets of proliferating cells, which may reflect their very aggressive nature in GBM.

Interestingly, although the majority of GBM cells corresponded mainly to one of four states, $15 \%$ of cells strongly expressed two different metamodules and, therefore, were defined as "hybrid" states. Some combinations of metamodules were rare, while others (AC-like/MES modules, NPClike/OPC-like modules, and AC-like/OPC-like modules) were relatively common. Thus, GBM cells are most often in one of four basic cellular states or an intermediate hybrid cellular state, each of which has a proliferative potential but with a higher proliferative activity for NPC-like and OPC-like states [24].

Each of the tumors contained cells in at least two of the four cellular states, with most tumors containing cells in all four states, but the frequencies of cellular states varied between tumors and even to some extent between different regions of the same tumor. Most of the tumors consisted mainly of NPC-like and OPC-like cells, or AC-like and 
MES cells. It is noteworthy that a similar picture was observed in adults and children.

The authors also showed that most of the obtained modules and cell types differ in certain driver events, typical for each specific module. For example, CDK4 amplification and overexpression of this gene's product are most common in NPC-like. In OPC-like, the most important driver event is the PDGFRA amplification with its significant expression increase. The $E G F R$ gene undergoes amplification and overexpression in AC-like, playing a major driver role. In MES, in contrast to the previous subtypes, the primary importance is not an increase in protooncogenes' activity but the deactivation of the NF1 anti-oncogene due to its mutation followed by a decrease in the neurofibromin expression activity [24].

\section{Conclusion}

Within the framework of this and previous reviews, we analyzed the array of modern molecular biological data on GBM and demonstrated that the variety of molecular properties of this type of tumor has two main dimensions: intertumoral and intratumoral. Methodological peculiarities and progressive development of genomic and post-genomic technologies determined the sequence of data accumulation in each of these directions. Numerous failures in the GBM effective target therapies' development based only on intertumoral heterogeneity assessment indicate the critical importance of developing precisely intratumoral heterogeneity issues. Despite the high level of methodological complexity, this problem is being actively studied. Nowadays the promising results have already been obtained: key cell populations that make up the pool of tumor cells in GBM have been identified, and their molecular metamodules have been characterized, and also the presumptive role of some cell populations and their subpopulations in ensuring the properties of tumor malignancy has been shown. Further research in this area opens up new, interesting perspectives for creating effective personalized diagnostic and treatment concepts.

\section{Сокращения}

GBM - glioblastoma

GSCs - glioma stem cells

TKR - tyrosine kinase receptors

CNS - central nervous system

AC - astrocyte-like metamodule

AKT3 - RAC-gamma serine/threonine-protein kinase

CDK6 - cyclin-dependent kinase 6

CDKN2A/B - cyclin-dependent kinase inhibitor 2A/B

EGFR - epidermal growth factor receptor

FGF1 - fibroblast growth factor type 1

FGFR 1 - fibroblast growth factor receptor type 1

MES - mesenchymal-like metamodules
MES1 - mesenchymal-like metamodule subtype 1 (hypoxia-independent)

MES2 - mesenchymal-like metamodule subtype 1 (hypoxia-dependent)

NOTCH2 - notch receptor type 2

$\mathrm{NPC}$ - neural progenitor-like metamodule

NPC1 - neural progenitor-like metamodule subtype 1

NPC2 - neural progenitor-like metamodule subtype 2

OPC - oligodendrocyte-progenitor-like metamodule

PDGFA - platelet-derived growth factor subunit A

PDGFRA - platelet-derived growth factor receptor A

PTEN - phosphatase and tensin homolog

RB1 - retinoblastoma protein type 1

TERT - telomerase reverse transcriptase

\section{References}

1. Patel AP, Tirosh I, Trombetta JJ, Shalek AK, Gillespie SM, Wakimoto H et al. Single-cell RNA-seq highlights intratumoral heterogeneity in primary glioblastoma. Science. 2014;344(6190):1396401. DOI: $10.1126 /$ science. 1254257 .

2. Никитин П.В., Рыжсова М.В., Зубова И.В., Панина T.H., Шугай C.В. Гетерогенность опухолевых клеток в глиобластомах. Архив патологии. 2019;81(3):27-36. DOI: 10.17116/patol20198103127.

Nikitin PV, Ryzhova MV, Zubova IV, Panina TN, Shugay SV. Heterogeneity of tumor cells in glioblastomas. Arkhiv patologii. 2019;81(3):27-36 (In Russ.). DOI: 10.17116/patol 20198103127.

3. Bedard PL, Hansen AR, Ratain MJ, Siu LL. Tumour heterogeneity in the clinic. Nature. 2013;501(7467):355-64. DOI: 10.1038/ nature 12627.

4. Ostrom QT, Gittleman H, Xu J, Kromer C, Wolinsky Y, Kruchko $C$ et al. CBTRUS Statistical Report: Primary brain and other central nervous system tumors diagnosed in the United States in 2009-2013. Neuro Oncol. 2016;18(suppl_5):v1-v75. DOI: $10.1093 /$ neuonc/now207.

5. Никитин П.В., Рыюсова М.В., Потапов А.А., Галстян С.А., Ким Д.С., Панина Т.Н., Шугай С.В., Старовойтов Д.В., Хохлова Е.А., Зубова И.В. Молекулярная и гистологическая гетерогенность глиобластом. Клиническая и экспериментальная морфология. 2020;9(3):5-11. DOI: 10.31088/CEM2020.9.3.511.

Nikitin PV, Ryzhova MV, Potapov AA, Galstyan SA, Kim DS, Panina TN, Shugai SV, Starovoitov DV, Khokhlova EA, Zubova IV. Glioblastoma molecular and histological heterogeneity. Clinical and experimental morphology. 2020;9(3):5-11 (In Russ.). DOI:10.31088/CEM2020.9.3.5-11.

6. Perry A, Aldape KD, George DH, Burger PC. Small cell astrocytoma: an aggressive variant that is clinicopathologically and genetically distinct from anaplasticoligodendroglioma. Cancer. 2004;101(10):2318-26. DOI: 10.1002/cncr.20625.

7. Perry A, Miller CR, Gujrati M, Scheithauer BW, Zambrano SC, Jost SC et al. Malignant gliomas with primitive neuroectodermal 
tumor-like components: a clinicopathologic and genetic study of 53 cases. Brain Pathol. 2009;19(1):81-90. DOI: 10.1111/j.17503639.2008.00167.x.

8. Homma T, Fukushima T, Vaccarella S, Yonekawa Y, Di Patre PL, Franceschi $S$ et al. Correlation among pathology, genotype, and patient outcomes in glioblastoma. J Neuropathol Exp Neurol. 2006;65(9):846-54. DOI: 10.1097/01. jnen.0000235118.75182.94.

9. Watanabe K, Tachibana O, Yonekawa Y, Kleihues P, Ohgaki H. Role of gemistocytes in astrocytoma progression. Lab Invest. 1997;76(2):277-84. PMID: 9042164.

10. Schittenhelm J, Psaras T. Glioblastoma with granular cell astrocytoma features: a case report and literature review. Clin Neuropathol. 2010;29(5):323-9. DOI: 10.5414/npp29323.

11. Lathia JD, Mack SC, Mulkearns-Hubert EE, Valentim CL, Rich JN. Cancer stem cells in glioblastoma. Genes Dev. 2015;29(12):1203-17. DOI: 10.1101/gad.261982.115.

12. Rispoli R, Conti C, Celli P, Caroli E, Carletti S. Neural stem cells and glioblastoma. Neuroradiol J. 2014;27(2):169-74. DOI: 10.15274/NRJ-2014-10028.

13. Osuka S, Van Meir EG. Overcoming therapeutic resistance in glioblastoma: the way forward. J Clin Invest. 2017;127(2):41526. DOI: $10.1172 /$ JCI89587.

14. Lan X, Jörg DJ, Cavalli FMG, Richards LM, Nguyen LV, Vanner RJ et al. Fate mapping of human glioblastoma reveals an invariant stem cell hierarchy. Nature. 2017;549:227-32. DOI: $10.1038 /$ nature23666.

15. Mao P, Joshi K, Li J, Kim SH, Li P, Santana-Santos L et al. Mesenchymal glioma stem cells are maintained by activated glycolytic metabolism involving aldehydedehydrogenase 1A3. Proc NatlAcadSci USA. 2013;110(21):8644-9. DOI: 10.1073/ pnas. 1221478110 .

16. Minata M, Audia A, Shi J, Lu S, BernstockJ, Pavlyukov MS et al. Phenotypic plasticity of invasive edge glioma stem-like cells in response to ionizing radiation. Cell Rep. 2019;26(7):1893-905. e7. DOI: 10.1016/j.celrep.2019.01.076.
17. Nathanson DA, Gini B, Mottahedeh J, Visnyei K, Koga T, Gomez $G$ et al. Targeted therapy resistance mediated by dynamic regulation of extrachromosomal mutant EGFR DNA. Science. 2014;343(6166):72-6. DOI: 10.1126/science.1241328.

18. Phillips HS, Kharbanda S, Chen R, Forrest WF, Soriano RH, Wu TD et al. Molecular subclasses of high-grade glioma predict prognosis, delineate a pattern of disease progression, and resemble stages in neurogenesis. Cancer Cell. 2006;9(3):157-73. DOI: 10.1016/j.ccr.2006.02.019.

19. Bhat KPL, Balasubramaniyan V, Vaillant B, Ezhilarasan $R$, Hummelink $K$, Hollingsworth $F$ et al.Mesenchymal differentiation mediated by NF- $\mathrm{KB}$ promotes radiation resistance in glioblastoma. Cancer Cell. 2013;24(3):331-46. DOI: 10.1016/j. ccr.2013.08.001.

20. Sottoriva A, Spiteri I, Piccirillo SG, Touloumis A, Collins VP, Marioni JC et al. Intratumor heterogeneity in human glioblastoma reflects cancer evolutionary dynamics. Proc Natl Acad Sci USA. 2013;110(10):4009-14. DOI: 10.1073/pnas. 1219747110

21. Aubry M, de Tayrac M, EtcheverryA, Clavreul A, Saikali S, Menei $P$ et al. From the core to beyond the margin: a genomic picture of glioblastomaintratumor heterogeneity. Oncotarget. 2015;6(14):12094-109. DOI: 10.18632/oncotarget.3297.

22. Abou-El-Ardat K, Seifert M, Becker K, Eisenreich S, Lehmann $M$, Hackmann $K$ et al. Comprehensive molecular characterization of multifocal glioblastoma proves its monoclonal origin and reveals novel insights into clonal evolution and heterogeneity of glioblastomas. Neuro Oncol. 2017;19(4):546--57. DOI: 10.1093/neuonc/now231.

23. Neftel C, Laffy J, Filbin MG, Hara T, Shore ME, Rahme GJ et al. An integrative model of cellular states, plasticity, and genetics for glioblastoma. Cell. 2019. DOI: 10.1016/j.cell.2019. 06.024 .

24. Filbin MG, Tirosh I, Hovestadt V, Shaw ML, Escalante LE, Mathewson ND et al. Developmental and oncogenic programs in H3K27M gliomas dissected by single-cell RNA-seq. Science. 2018;360(6386):331-5. DOI: 10.1126/science.aao4750.

\section{Author information}

Pavel V. Nikitin - Researcher, Laboratory of Neuromorphology and Molecular Diagnostics, N.N. Burdenko National Medical Research Center of Neurosurgery.

https://orcid.org/0000-0003-3223-4584

Marina V. Ryzhova - Dr. Sci. (Med.), Professor, Head of the Pathology Department, N.N. Burdenko National Medical Research Center of Neurosurgery. https://orcid.org/0000-0001-7206-6365

Alexander A. Potapov - Dr. Sci. (Med.), Professor, Academician of the Russian Academy of Sciences, Director of the N.N. Burdenko National Medical Research Center of Neurosurgery.

https://orcid.org/0000-0001-8343-3511

Suzanna A. Galstyan - Resident, Pathology Department, N.N. Burdenko National Medical Research Center of Neurosurgery. https://orcid.org/0000-0001-9953-6654

Daria S. Kim - Pathologist, Pathology Department, N.N. Burdenko National Medical Research Center of Neurosurgery. https://orcid.org/0000-0003-2354-6930 
Tatyana N. Panina - Pathologist, Pathology Department, N.N. Burdenko National Medical Research Center of Neurosurgery. https://orcid.org/0000-0001-6156-0085

Svetlana V. Shugay - Pathologist, Pathology Department, N.N. Burdenko National Medical Research Center of Neurosurgery. https://orcid.org/0000-0001-8079-8523

Dmitry V. Starovoitov - Biologist, Pathology Department, N.N. Burdenko National Medical Research Center of Neurosurgery. https://orcid.org/0000-0002-1879-393X

Ekaterina A. Khokhlova - Resident, Pathology Department, N.N. Burdenko National Medical Research Center of Neurosurgery. https://orcid.org/0000-0003-3330-9779

Irina V. Zubova - Laboratory Technician, Pathology Department, N.N. Burdenko National Medical Research Center of Neurosurgery. https://orcid.org/0000-0003-4210-0360 